\title{
Extremely shallow spawning of perch (Perca fluviatilis L.): the roles of sheltered bays, dense semi-terrestrial vegetation and low visibility in deeper water
}

\author{
M. Čech ${ }^{(1) \star}$, J. Peterka(1), M. Říha(1), L. Vejř́í( ${ }^{(1)}$, T. Jůza ${ }^{(1)}$, M. Kratochvíl(1), \\ V. Draštík(1) ${ }^{(1)}$ M. Muška(1) ${ }^{(1)}$. Znachor ${ }^{(1)}$, J. Kubečka(1) \\ Received August 18, 2012
}

Revised November 3, 2012

Accepted November 5, 2012

Key-words:

Rímov Reservoir, Chabařovice

Lake,

SCUBA diving,

Reed

canarygrass

Phalaris

arudinacea,

Goat willow Salix

caprea,

egg strands

\section{ABSTRACT}

The roles of wind protected bays, presence of littoral vegetation and light attenuation in the water column on spawning site selection and depth of egg strands deposition by perch Perca fluviatilis was studied in Rímov Reservoir, Czech Republic, in the years 2007 and 2011 using boat observation and SCUBA divers. The data were compared with results from Chabařovice Lake, Czech Republic, where similar monitoring took place in 2007-2010 and 2012. In shallow water of Rímov Reservoir, the density of egg strands was significantly higher in grass bays compared to both rocky bays and the main reservoir body. Most egg strands were deposited in water less than $0.5 \mathrm{~m}$ deep on reed canarygrass Phalaris arudinacea. In year when the littoral vegetation was absent perch were forced to spawn significantly deeper on various types of woody structures. In Rímov Reservoir, which is less vulnerable to wind, $91.1 \%$ of egg strands were spawned in water $\leqslant 3 \mathrm{~m}$ deep. In contrast, in the wind exposed Chabařovice Lake, even in the presence of littoral vegetation, $90.5 \%$ of egg strands were found at depths greater than $3 \mathrm{~m}$. In Chabařovice Lake, the light penetrated to three times greater depth compared to Rímov Reservoir and, similarly, the depth limit to which $95 \%$ of egg strands were spawned was three times greater in this lake compared to Rímov Reservoir. This study is the first contribution showing the role of water transparency in controlling the depth distribution of perch egg strands in lakes and reservoirs.

\section{RÉSUMÉ}

Reproduction de la perche en eau très peu profonde (Perca fluviatilis L.) : rôle des baies abritées, de la végétation semi-terrestre dense et de la faible visibilité dans les eaux plus profondes

Mots-clés : réservoir Římov, lac Chabařovice, plongée autonome, Phalaris roseau
Les rôles des baies protégées du vent, de la présence de végétation littorale et de l'atténuation de la lumière dans la colonne d'eau sur le choix du site de ponte et la profondeur du positionnement des rubans d'œufs par la perche Perca fluviatilis ont été étudiés dans le réservoir Rímov, République tchèque, dans les années 2007 et 2011 par observation en bateau et plongée autonome. Les données ont été comparées avec les résultats du lac Chabařovice, République tchèque, où un suivi similaire a eu lieu en $2007-2010$ et en 2012 . En eau peu profonde du réservoir Římov, la densité des rubans d'œufs était significativement plus élevée dans les

(1) Biology Centre, Academy of Sciences of the Czech Republic, Institute of Hydrobiology, Na Sádkách 7, 37005 České Budějovice, Czech Republic

* Corresponding author: carcharhinusleucas@yahoo.com 


\section{Phalaris}

arudinacea,

Saule marsault

Salix caprea, rubans d'œufs baies herbeuses par rapport aux baies rocheuses et à l'ensemble du réservoir. La plupart des rubans d'œufs ont été déposés à moins de $0,5 \mathrm{~m}$ de profondeur sur le Phalaris roseau Phalaris arudinacea. L'année où la végétation littorale était absente, les perches ont été forcées de se reproduire de façon significativement plus profonde sur différents types de structures ligneuses. Dans le réservoir Římov, qui est moins vulnérable au vent, $91,1 \%$ des brins d'œufs ont été déposés dans l'eau $\leqslant 3 \mathrm{~m}$ de profondeur. En revanche, dans le lac Chabařovice exposé au vent, même en présence la végétation littorale, 90,5\% des rubans d'œufs ont été trouvés à des profondeurs supérieures à $3 \mathrm{~m}$. Dans le lac Chabařovice, la lumière pénètre trois fois plus en profondeur que dans le réservoir Římov et, de même, la limite de la profondeur à laquelle $95 \%$ des rubans d'œufs ont été déposés était trois fois plus élevée dans ce lac que dans le réservoir Rímov. Cette étude est la première contribution montrant le rôle de la transparence de l'eau dans le contrôle de la distribution en profondeur des rubans d'œufs de perche dans les lacs et les réservoirs.

\section{INTRODUCTION}

The success of any fish species is ultimately determined by the ability of its members to reproduce successfully in a fluctuating environment and thereby to maintain viable populations (Moyle and Cech, 1982; Houde, 2008). Parental choice of e.g. an appropriate spawning site or spawning depth, is essential for the development and survival of the new generation since immobile eggs are vulnerable both to unfavorable biotic and mainly abiotic conditions (Wootton, 1998). In perch [Perca fluviatilis L. in Eurasia and P. flavescens (Mitchill) in North America], the ability to react to different environmental conditions is well known and has been documented in their selection of appropriate spawning sites (Holčík, 1969; Jones, 1982; Treasurer, 1983; Probst et al., 2009; Snickars et al., 2010; Čech et al., 2011; 2012), spawning depth (Gillet and Dubois, 1995; Newsome and Aalto, 1987; Williamson et al., 1997; Huff et al., 2004; Čech et al., 2009, 2010), as well as in selection of an appropriate spawning substrate (Čech et al., 2009, 2012) or temperature for incubation of their egg strands (Gillet and Dubois, 1995, 2007; Čech et al., 2011, 2012). It should be taken into account that many factors responsible for the success of perch reproduction may interact with each other, particularly spawning site and spawning substrate (Jones, 1982; Treasurer, 1983), spawning depth and spawning substrate (Čech et al., 2009, 2010) or spawning depth and temperature of incubation (Gillet and Dubois, 1995; Čech et al., 2012).

Although perch is a plastic species, it seems likely that, in general, there are two basic behavioural patterns in its reproduction and in the depth distribution of its egg strands. In small lakes and reservoirs, the majority of egg strands are deposited to a maximum depth of only 2-3 m or even shallower (Holčík, 1969; Viljanen and Holopainen, 1982; Treasurer, 1983; Urho, 1996; Smith et al., 2001). These water bodies have dense stands of aquatic macrophytes and/or they are protected from the wind (or they have at least sheltered bays and islands where spawning predominantly takes place). In contrast to that, in large or middle-sized lakes exposed to winds from at least some directions, perch spawning occurs down to much greater depths and egg strands deposited to a depth of 10,15, or even $20 \mathrm{~m}$, are not rare (Newsome and Aalto, 1987; Gillet and Dubois, 1995, 2007; Probst et al., 2009; Čech et al., $2009,2010)$. In these water bodies, shallow depth layers are completely ignored by spawning perch, most likely because of the damaging effect of waves generated by wind or car ferries and passenger cruise ships. Clady and Hutchinson (1975) showed that as a result of one day of high winds, large quantities of perch egg strands were washed ashore at a number of locations on the windward shoreline of Oneida Lake. The wind/wave action could not only damage the egg strands mechanically, but could also induce large internal seiches. This extreme mass movement of water may cause thermal shocking of developing embryos (Aalto and Newsome, 1989) and increase egg mortality or the presence of body abnormalities in hatched fry, leading to greater susceptibility to predation (Newsome and Aalto, 1987). Especially in shallow water, the abrasive wave action could also impose the danger of silt and other 


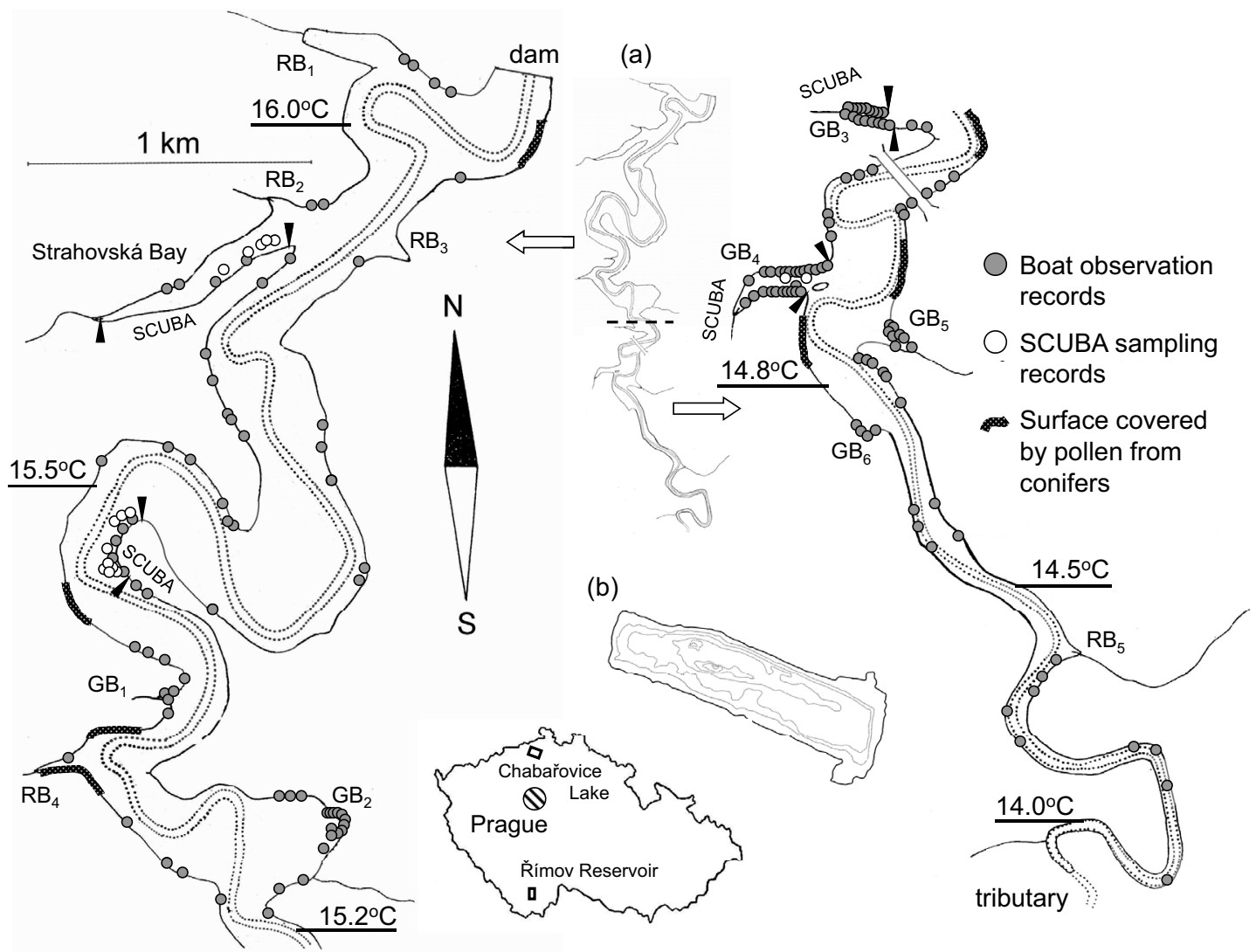

\section{Figure 1}

Contour maps of (a) Římov Reservoir and (b) Chabařovice Lake and their location in the Czech Republic. Grey dots indicate places where egg strands of perch were found during the boat observation of Rímov Reservoir (depths 0-1 m; spring 2011), white dots indicate places where egg strands of perch were found during the SCUBA sampling (depths 1-8 m; spring 2011; selected localities only, defined by black arrows). RB, rocky bay. GB, grass bay. The shoreline of Rímov Reservoir where the water surface was covered by pollen from blooming conifers was not sampled. Littoral surface water temperature measured along the longitudinal profile of the reservoir on 27 April between 9 and 11 a.m. is also shown.

forms of sedimentation, which would adversely affect the development of perch eggs (Jones, 1982).

A clear exception to these two general patterns is Lake La Gombe, an inundated quarry pit (area $\sim 1$ ha, spring Secchi disc depth $>10 \mathrm{~m}$ ), well protected against wind. Apart from trees and branches, no submerged macrophytes are present in the lake. In this water body, the perch spawn to a maximum depth of $26 \mathrm{~m}$ (95.5\% of egg strands were deposited at 3-20 m depths) and, as in large or middle-sized lakes exposed to winds, spawning perch in Lake La Gombe completely ignore the shallow depth layers (Dalimier et al., 1982).

Perch is a visually orienting fish primarily active in daylight (Ali et al., 1977; Jacobsen et al., 2002). Also perch spawning takes place during daylight hours (Hergenrader, 1969). It therefore seems likely that not only damaging waves in shallow water and appropriate spawning substrate and temperature in deeper water control the depth distribution of perch egg strands in lakes and reservoirs, but that light penetrating through the water column, could also do so. To test this and, similarly, to test the role of sheltered bays and submerged macrophytes on the depth at which egg strands are deposited, the data sets from two water bodies, Římov Reservoir and Chabařovice Lake, were used. These water bodies are similar in size but differ markedly in shape (Figure 1), in exposure to wind and in the transparency of their water. 
The main questions of the present study were: (1) Does the density of egg strands along the shoreline of Rímov Reservoir differ in the main reservoir body and in sheltered bays? (2) Does the depth of egg strands deposition in Římov Reservoir differ between years with and without submerged semi-terrestrial vegetation present in shallow littoral zones? (3) Does the depth range in which egg strands are deposited in Rímov Reservoir and in Chabařovice Lake correspond to depths at which light is available?

The study is part of a long-term project focusing on succession processes in a restored opencast mine lake (Chabařovice) where aquatic restoration has been applied.

\section{MATERIALS AND METHODS}

\section{$>$ STUDY AREA}

The study was carried out in the meso- to eutrophic Římov Reservoir, Czech Republic $\left(48^{\circ} 50^{\prime} \mathrm{N}, 14^{\circ} 29^{\prime} \mathrm{E} ; 170 \mathrm{~km}\right.$ south of Prague; Figure 1). The data from Rímov Reservoir were compared with previously published results of Čech et al. $(2009,2010,2011,2012)$ from the oligo- to mesotrophic Chabařovice Lake, Czech Republic $\left(50^{\circ} 39^{\prime} \mathrm{N}, 13^{\circ} 56^{\prime} \mathrm{E} ; 80 \mathrm{~km}\right.$ northwest of Prague; Figure 1).

Římov Reservoir was created by damming the Malše River (in 1978), which is the main reservoir inflow. The reservoir has an area of 210 ha, maximum surface elevation of $471 \mathrm{~m}$ a.s.l., length of $10 \mathrm{~km}$ and mean width of $\sim 200 \mathrm{~m}$. The maximum depth is $45 \mathrm{~m}$, the mean depth $16 \mathrm{~m}$, the volume is $33.6 \times 10^{6} \mathrm{~m}^{3}$ and the mean theoretical retention time $\sim 100$ days. The mean annual concentration of dissolved organic carbon (DOC) is $\sim 6 \mathrm{mg} \cdot \mathrm{L}^{-1}$. In most years, the littoral zone of the canyon-shaped Římov Reservoir is deprived of aquatic macrophytes due to the steep banks and water level fluctuation (continuous lowering of the water level for 1-2 cm per day especially in summer and early fall, i.e. in dry months). In 2011 (the year of the main sampling), however, the administrator of the reservoir, the Vltava River Authority, increased the water level to the extent that, in some localities, dense stands of semiterrestrial vegetation, especially reed canarygrass Phalaris arudinacea, were flooded (surface elevation $469.5 \mathrm{~m}$ a.s.I.). This unusual situation occurred for the whole spring of 2011. Considering perch spawning, at that time the shoreline of the whole reservoir could be divided into three different types: (1) the main reservoir body and the large Strahovská Bay, (2) grass bays, (3) rocky bays (Figure 1). The shoreline of the rocky bays was composed of rocks or steep rubble slopes. Apart from stumps and sporadically logged trees no submerged vegetation was present. On the other hand, the much less steep shorelines of the grass bays were composed of mud, sand and rubble. Dense stands of semi-terrestrial vegetation, reed canarygrass, were present. The shoreline of the main reservoir body, as well as the shoreline of the large Strahovská Bay, was a mixture of two previous types accompanied by stretches of sandy and muddy beaches or slowly eroding clay slopes. In 2007 (the year of preliminary sampling), on the other hand, the reservoir was held at its typical low water level (surface elevation $468.8 \mathrm{~m}$ a.s.I.) and no submerged vegetation was present in the littoral zone. Grass bays noted in 2011 were, in 2007, not qualitatively different from most stretches of the main reservoir body.

The surrounding landscape of Římov Reservoir, mostly represented by the former, deep river valley, is covered by forest ( $98 \%$ coverage), which, together with meanders, makes this water body less vulnerable to winds and the resulting wave action (winds of a speed $>6 \mathrm{~m} \cdot \mathrm{s}^{-1}$ rarely occur; Czech Hydrometeorological Institute, unpubl. data). Small bays (Figure 1) are protected from the wind from most directions. Perch is one of the dominant fish species in the reservoir (Říha et al., 2009), showing, at least in some years, very high reproduction success (Čech and Kubečka, 2006; Jůza et al., 2010, 2012; Kratochvíl et al., 2012).

Chabařovice Lake is a newly created, opencast mine lake where aquatic restoration started in 2001. It has an area of 250 ha, surface elevation of $145.7 \mathrm{~m}$ a.s.l., volume of $35 \times 10^{6} \mathrm{~m}^{3}$, mean width of $\sim 800 \mathrm{~m}$ and maximum depth of $25 \mathrm{~m}$. The concentration of DOC during the perch spawning period is $6.2 \mathrm{mg} \cdot \mathrm{L}^{-1}$ (Čech et al., 2011). The surrounding landscape is deforested which makes this plate-like lake vulnerable to winds from all directions (winds of a 
speed of $12-15 \mathrm{~m} \cdot \mathrm{s}^{-1}$ frequently occur; Čech et al., 2011, 2012). This water body initially had no obvious limitation to perch spawning activity in terms of spawning substrates, which were numerous (e.g. dead trees, dislodged branches, bushes, worm weed Artemisia sp., beds of dead and live common reed Phragmites communis, curly pondweed Potamogeton crispus, Eurasian water milfoil Myriophyllum spicatum and common stonewort Chara vulgaris) and at least some of them were present down to the deepest part of the lake (Čech et al., 2009, 2010). Common reed, reed canarygrass and other semi-terrestrial or flooded terrestrial vegetation were frequently present in the littoral part of the lake (Čech et al., 2011). Perch is the most abundant predatory fish in the lake, and a key species, significantly affecting the whole lake ichthyofauna (Čech et al., 2009, 2011, 2012).

During the perch spawning period the water column is thermally stratified in both Rímov Reservoir and Chabařovice Lake. The concentration of dissolved oxygen in the upper $20 \mathrm{~m}$ of the water column never drops below $5 \mathrm{mg} \cdot \mathrm{L}^{-1}$ (Čech and Kubečka, 2006; Čech et al., 2010). A high concentration of DOC ( 6 mg. $\mathrm{L}^{-1}$; category of higher-DOC lakes according to the classification of Huff et al., 2004) in both Rímov Reservoir and Chabařovice Lake suggests that perch, in an effort to protect their eggs against damaging ultraviolet radiation (UVR), are not forced to spawn in deep water and avoid shallow depths, i.e. UVR does not control the depth distribution of egg strands in these water bodies (Čech et al., 2011). A crucial role of UVR in controlling the depth of egg strands deposition has been shown by Huff et al. (2004) for low-DOC Lake Giles, Pennsylvania (DOC $\left.1.1 \mathrm{mg} \cdot \mathrm{L}^{-1}\right)$. In this lake, perch spawn to a maximum depth of $14 \mathrm{~m}$ (median spawning depth 5-6 $\mathrm{m}$ ) and avoid shallow water $<2 \mathrm{~m}$ deep (Huff et al., 2004).

\section{$>$ SAMPLING}

The whole shoreline of Rímov Reservoir, down to a depth of $1 \mathrm{~m}$, was sampled visually from the boat using polarized glasses on 19, 27 and 28 April 2011. The depths of egg strands' deposition was measured using a ruler with an accuracy of $0.1 \mathrm{~m}$, the identification of spawning substrate was done to the plant species or functional group (e.g. reed canarygrass, logged trees, exposed roots of tree stumps). In total, $23.92 \mathrm{~km}$ of the shoreline were sampled, representing the main reservoir body $(19.19 \mathrm{~km})$, rocky bays $(1.39 \mathrm{~km})$, grass bays $(1.82 \mathrm{~km})$ and the large Strahovská Bay (1.52 km; Figure 1).

In selected localities the distribution of egg strands in deeper layers was monitored using two SCUBA divers on 4 and 16 May 2011 (localities marked as SCUBA, selected according to the previous work of Kubečka (1992) as localities showing high perch prespawning activity; Figure 1). In total, $2.23 \mathrm{~km}$ of the shoreline was sampled in depth layers of 1-4 and 4-8 $\mathrm{m}$ using dense zig-zag trajectories (comprising 12 hours of research underwater). Each diver sampled the space of $1 \mathrm{~m}$ on either side of him. Similarly to the boat observations, the divers recorded the depth of egg strands deposition and the type of spawning substrate. The information was noted underwater on a plastic slate for each individual egg strand.

The data from 2011 were compared with those from 2007, which were sampled in the same way using both SCUBA sampling and boat observation. In 2007, however, only selected localities of Rímov Reservoir were sampled (on 19 April and 4 May; again localities marked as SCUBA; Figure 1).

In 2007 and similarly in 2011, the progress of perch spawning period was monitored using Breder traps and fyke-nets as described from the same reservoir by Kubečka (1992). In 2007, six Breder traps and four fyke-nets were continuously set along the whole longitudinal profile of the reservoir from 6 April to 2 May. Nets were lifted three times a week and caught 1239 perch individuals (in total). Over $84 \%$ of caught perch females were still pregnant (unspawned fish with extreme bulging of the belly; according to Čech et al., 2009) till 16 April $\left(n_{\text {female }}=13\right)$. From 18 April onward this proportion dropped to less than $4 \%\left(n_{\text {female }}=27 ; \mathrm{M}\right.$. Cech, J. Kubečka, unpubl. data).

In 2011, six Breder traps and 29 fyke-nets were set from 10 April to 9 May. Nets were lifted two times a week and caught 4846 perch individuals. Over $97 \%$ of caught perch females 
were still pregnant till 21 April $\left(n_{\text {female }}=159\right)$. From 26 April onward this proportion dropped to less than $30 \%\left(n_{\text {female }}=27\right)$. The last pregnant female was caught on 2 May (M. Ríha, J. Kubečka, unpubl. data).

Following the data from Breder traps and fyke-nets, the research on the distribution of perch egg strands in Rímov Reservoir started immediately after the peak of perch spawning in both 2007 and 2011.

The depth distribution of perch egg strands in Chabařovice Lake was sampled in 2007-2010 (Čech et al., 2009, 2010, 2011, 2012) and in 2012 (M. Čech, J. Peterka, unpubl. data) using the boat and SCUBA divers in a similar way to the sampling in Rímov Reservoir.

The light (PAR, photosynthetically active radiation) attenuation in the water column was measured using an LICOR LI-250 underwater light meter at noon in mid-May 2011 (Římov Reservoir) and 2012 (Chabařovice Lake). Since the values of ambient PAR at a particular depth might vary greatly over the course of a day, reflecting the actual weather condition (rainy, cloudy or sunny weather in particular), for better comparison of the real situation in Rímov Reservoir and Chabařovice Lake the original data were recalculated to $500 \mu \mathrm{mol} \mathrm{m} \mathrm{m}^{-2} \cdot \mathrm{s}^{-1}$ of PAR entering the water surface. The water transparency in both water bodies was measured using a Secchi disc.

The data from Rímov Reservoir were tested using one-way ANOVA (comparison of the density of egg strands in a 0-1 $\mathrm{m}$ depth along the shoreline of the main reservoir body, rocky bays and grass bays; comparison of the micro-depth distribution of egg strands in the shallow, littoral zone of the main reservoir body and in bays) and Kruskal-Wallis test (comparison of the depth distribution of egg strands in 2007 and 2011 along the whole vertical profile sampled; selected localities only, sampled using both SCUBA divers and from the boat). Tukey HSD post-hoc comparison for unequal $n$ (Tukey test) was used after ANOVA for detailed identification of significant difference between the density of egg strands in a 0-1 m depth along the shoreline of the main reservoir body, rocky bays and grass bays. The large Strahovská Bay was excluded from the first two ANOVA analyses, because, despite the fact that it is a bay, the shoreline composition more closely resembles the main reservoir conditions. Perch spawning activity corresponds well to this fact (cf. Figure 1). The comparison of results from Rímov Reservoir with the data from Chabařovice Lake, was done exclusively for the selected localities sampled using both SCUBA divers and from the boat.

\section{RESULTS}

During the boat observations in 2011, 156 egg strands were found along the shoreline of the whole Římov Reservoir (70 in bays of various types, 86 in the main reservoir body; Figure 1). The density of egg strands was significantly higher in grass bays compared to rocky bays and the main reservoir body (ANOVA; $F_{2,16}=60.24, P<0.001$; Figure 2 ). The vast majority of egg strands $(98.1 \%)$ were in water less than $0.5 \mathrm{~m}$ in depth. Nevertheless, in bays the egg strands were spawned in even shallower water compared to the main reservoir body (ANOVA; $F_{1,150}=18.53, P<0.001$ ), mostly in a depth of $0-0.1 \mathrm{~m}$, i.e. touching, or almost touching, the water surface. During the additional SCUBA sampling another 17 egg strands were found up to a depth of $7 \mathrm{~m}$ (Figure 1, 3a).

In shallow water, most of the egg strands were deposited on reed canarygrass $170.5 \%$ in the case of the whole reservoir but $80 \%$ in bays), the rest were found on goat willow (Salix caprea; $19.2 \%$ in the whole reservoir but only $10.8 \%$ in bays), logged trees, branches, raspberry Rubus ideaus, blackberry $R$. fruticosus, dog rose Rosa canina and common rush Juncus effusus. In deeper water, the egg strands were found on logged trees, branches and on exposed roots of tree stumps.

In 2007, all 60 egg strands were found exclusively on goat willow, logged trees, branches and on exposed roots of tree stumps in a depth of 0.1-5 m. Due to the complete absence of partly submerged, dense grass in the littoral zone (because of the low water level), much less preference for very shallow water was observed and the egg strands were deposited significantly 


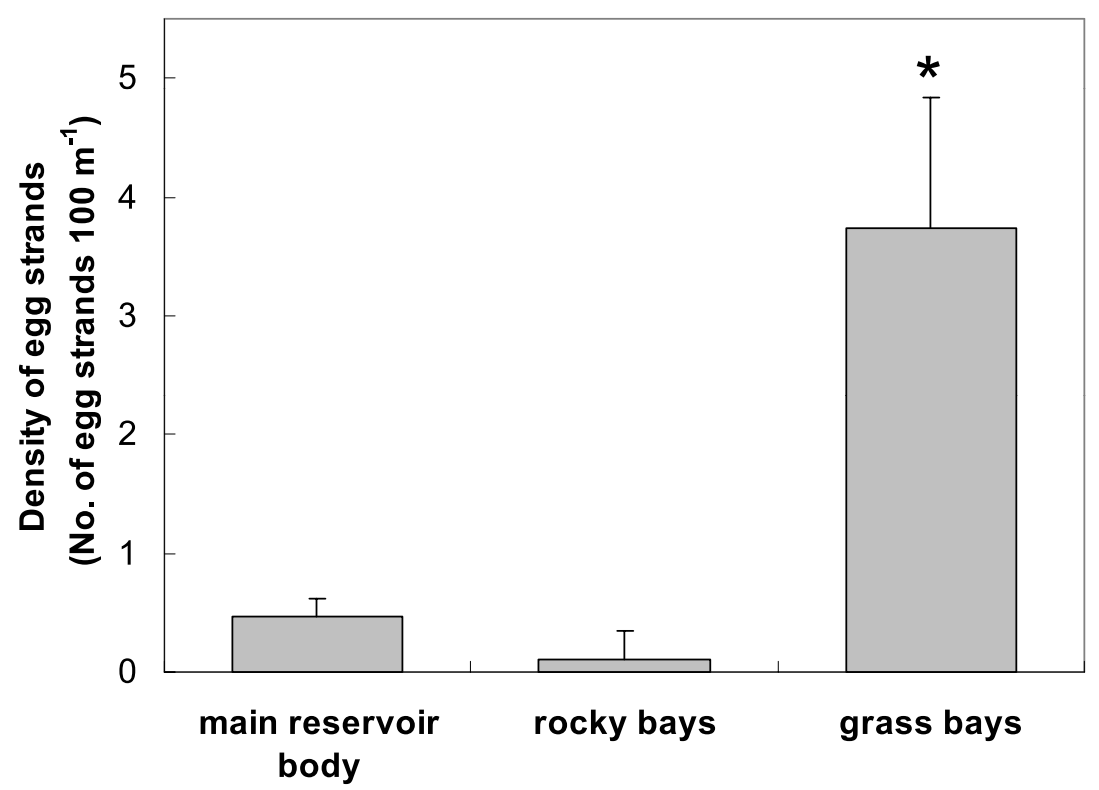

\section{Figure 2}

Comparison of the density of egg strands of perch along the shoreline of the main body of Rímov Reservoir and in rocky and grass bays (spring 2011; data from the boat observation only; depths $0-1 \mathrm{~m}$ ). The asterisk indicates the category with significantly higher density of egg strands (Tukey test: $P<0.001$ ).

(a)

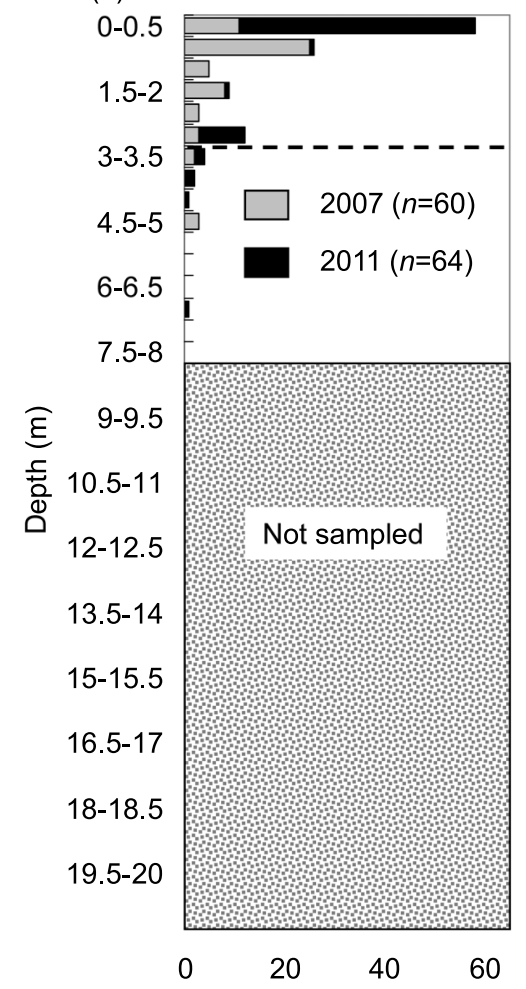

No. of egg strands (b)

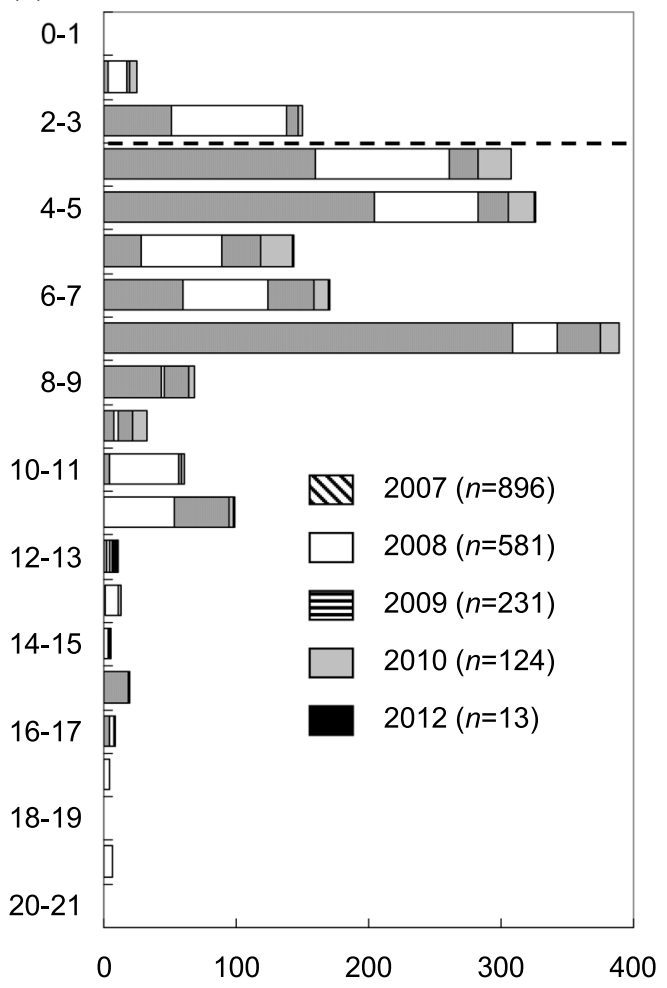

No. of egg strands

\section{Figure 3}

Depth distribution of egg strands of perch in (a) Řimov Reservoir in spring 2007 and 2011 (selected localities only, sampled by both SCUBA divers and from the boat, cf. Figure 1) and in (b) Chabarovice Lake in spring 2007-2010 and 2012. Dashed lines indicate the depth of $3 \mathrm{~m}$. 


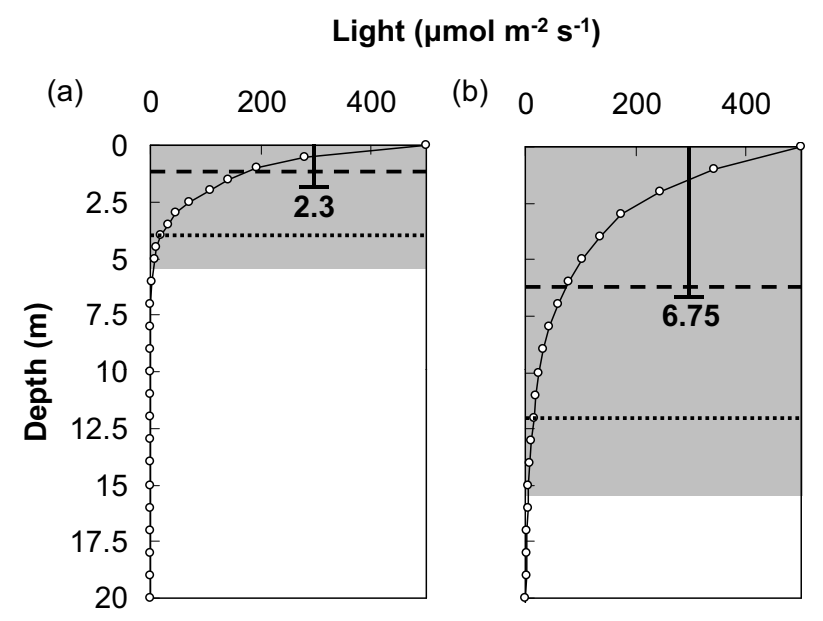

\section{Figure 4}

Comparison of the light (PAR) attenuation in the water column of (a) Rímov Reservoir and of (b) Chabařovice Lake measured around noon in mid-May. The original data were recalculated to $500 \mu \mathrm{mol} \cdot \mathrm{m}^{-2} \cdot \mathrm{s}^{-1}$ of PAR entering the water surface. Grey bars indicate the zone of the water column where PAR reached values of at least $1 \%$ of the surface value (i.e. the zone of photosynthetic activity). The vertical bars show the Secchi disk depths. Dashed lines indicate the average depth of egg strands in Rímov Reservoir in 2007 and 2011 (pooled data) and in Chabařovice Lake in 2007-2010 and 2012 (pooled data). Dotted lines indicate the depth limit to which 95\% of egg strands were spawned.

deeper compared to the 2011 situation (mostly in a depth of $0.5-1 \mathrm{~m}$; Kruskal-Wallis test; $H_{1,124}=26.69, P<0.01$; Figure 3a).

In Římov Reservoir, $91.1 \%$ of egg strands were spawned in water $\leqslant 3$ m deep $(91.7 \%$ in 2007 , $90.6 \%$ in 2011; Figure 3a). In contrast to that, in Chabařovice Lake, $90.5 \%$ of egg strands were found at depths greater than $3 \mathrm{~m}$ (88.1-93.5\% in 2007-2010). Shallow depth layers were rarely used for spawning and the $0-1 \mathrm{~m}$ depth layer was completely ignored during all the years of sampling (Figure 3b).

In Chabařovice Lake, the light attenuation in the water column was three times lower compared to Rímov Reservoir (light was available down to c. $15 \mathrm{~m}$ and c. $5 \mathrm{~m}$ respectively; Figure 4). Similarly, in this lake the depth limit to which $95 \%$ of egg strands were spawned was three times greater compared to Římov Reservoir (12 m and $4 \mathrm{~m}$ respectively; Figure 4 and $c f$. with Figure 3).

\section{DISCUSSION}

Wind, and the resulting wave action, has been suggested to be one of the crucial factors affecting site selection for spawning by perch in lakes (Jones, 1982; Treasurer, 1983). Similarly in Rímov Reservoir, although this water body is, due to its shape and formation of the surrounding landscape, less vulnerable to winds, perch significantly preferred small sheltered bays for egg strands deposition compared to the main reservoir body. In these bays perch also spawn in shallower water than in the main reservoir body. However, the reproducing perch used only bays with dense stands of submerged semi-terrestrial vegetation (grass bays) and completely avoided bays where this spawning substrate was absent (rocky bays). This finding corresponds to the previous observations of Jones (1982), Treasurer (1983), Urho (1996) and Snickars et al. (2010) that appropriate spawning substrate, especially in shallow water, is another crucial factor affecting spawning site selection by perch. As has been shown in the present study, even in the same water body, the presence or absence of shallow water vegetation can strongly influence the depth distribution of perch egg strands. When present, perch tried to spawn in as shallow water as possible (year 2011 situation). Then the eggs could benefit from higher temperature and significant shortening of incubation time (Guma'a, 1978). 
When shallow water vegetation was absent (year 2007 situation), the perch were forced to spawn in deeper water on logged trees, branches or exposed roots of tree stumps as the only structures to which the egg strands could be successfully attached. At that time, any egg strand deposited in very shallow water (not attached to any structure) would in fact suffer from either being washed ashore (Clady and Hutchinson, 1975) even by small waves (or to be mechanically damaged) or simply being removed by gradual, slow movement of the water to a less favorable location (Probst et al., 2009), particularly onto a muddy reservoir bottom, since egg strands are slightly heavier than water (Mansueti, 1964).

In contrast, in the case of the wind exposed Chabařovice Lake, the shallow water depths (0-1 $\mathrm{m}$ depth in particular but also 1-2 $\mathrm{m}$ ) were clearly avoided by spawning perch even in the presence of various types of submerged vegetation (Čech et al., 2011). A fear of the damaging effect of waves on deposited egg strands is evident in this lake (Čech et al., 2009) and has been experimentally proved by using artificial spawning substrates in various depths and at various localities (Čech et al., 2012). The same avoidance of shallow waters due to wave action has also been well documented for spawning perch in large prealpine lakes such as Lake Geneva (Gillet and Dubois, 1995, 2007) or Lake Constance (Probst et al., 2009).

Apart from exceptional cases of extreme mass water movement causing large internal seiches (Newsome and Aalto, 1987; Čech et al., 2011, 2012), in deeper water the distribution of perch egg strands is believed to be controlled mainly by the position of a $12{ }^{\circ} \mathrm{C}$ water layer (Kubečka, 1992; Gillet and Dubois, 1995, 2007; Čech et al., 2012). Recently, Čech et al. (2012) have suggested that especially at the end of the spawning season, perch do not react to the actual temperature of the water column and even in a situation when the water temperature is $6-8{ }^{\circ} \mathrm{C}$, i.e. well below the optimum for egg strand incubation $\left(10-12{ }^{\circ} \mathrm{C}\right.$; Swift, 1965), they spawn deeper and deeper. They seem to follow their inner clock, assuming that "normally" the shallower depth layers are too warm for successful embryo development. This is the reason why in thermally suboptimal years the egg strands could also be found in very deep ( $\gg 10 \mathrm{~m})$ and very cold water (5-6 ${ }^{\circ} \mathrm{C}$; Čech et al., 2012; M. Čech, pers. observation).

In large or middle-sized lakes exposed to wind the harmful effect of waves on perch egg strands is supposed to extend to a depth of $3 \mathrm{~m}$ or less (Gillet and Dubois, 2007; Čech et al., 2012). Then the question remains, why perch do not spawn the gross majority of their egg strands to a depth of 3-6 $\mathrm{m}$ (considering $\sim 3 \mathrm{~m}$ depth shift in these water bodies) following the distribution pattern from Římov Reservoir (this study) or e.g. Klíčava Reservoir (Holčík, 1969), and why they frequently spawn to a depth of 10 or $15 \mathrm{~m}$ or even deeper (Gillet and Dubois 1995, 2007; Probst et al., 2009; Čech et al., 2009, 2010). An extreme example is the wind protected Lake La Gombe where perch spawn to a depth of $26 \mathrm{~m}$ (Dalimier et al., 1982). This question could be asked also from the opposite viewpoint. Why perch in Římov Reservoir restricted their spawning to shallow depths and why records of egg strands from water $>3 \mathrm{~m}$ deep are so sporadic?

Perch is a visually orientating fish (Ali et al., 1977; Jacobsen et al., 2002) and, as shown by Hergenrader (1969), perch spawning also takes place during daylight hours (most probably, visual communication plays an important role in perch spawning/courtship rituals). Visibility in the water column is therefore essential for spawning perch. In the meso- to eutrophic Římov Reservoir visibility in the water column is relatively poor (Secchi disc depth $2.3 \mathrm{~m}$ ) and complete darkness started around the depth of $\sim 6 \mathrm{~m}$. Perch spawning is therefore almost exclusively restricted to the upper $4 \mathrm{~m}$ of the water column. Similarly, in Klíčava Reservoir (Secchi disc depth 2.9 m; Rozmajzlová-Řeháčková, 1966) the gross majority of egg strands were found in water up to $1.5 \mathrm{~m}$ deep and only isolated egg strands were found down to $4 \mathrm{~m}$ deep (Holčík, 1969). In highly turbid, hypertrophic ponds perch spawn in very shallow water with egg strands frequently touching, or almost touching, the water surface (M. Čech, pers. observation).

In contrast, in the oligo- to mesotrophic Chabařvice Lake (Secchi disc depth $6.75 \mathrm{~m}$ ) the visibility in the water column is three times greater than in Rímov Reservoir and in this lake perch frequently spawn to a depth of $12 \mathrm{~m}$ or even deeper (Čech et al., 2009, 2010, 2011, 2012). Similarly, in Lake Geneva or Lake Constance where the process of reoligotrophication 
is in progress (Secchi disc depth 6-10 m; Gerdeaux and Perga, 2006; Anneville et al., 2008) perch frequently spawn up to a depth of over $10 \mathrm{~m}$ (Gillet and Dubois, 1995, 2007; Probst et al., 2009). High visibility in the water column is likely the reason for deep spawning of perch in oligotrophic Lake La Gombe (Dalimier et al., 1982).

It seems that there is little benefit for perch to spawn in deeper water ( $\gg 6 \mathrm{~m})$. There the spawning takes place later in the season and cold water, which warming is usually very slow, further prolongs the incubation time of the eggs deposited. In Chabařovice Lake, Čech et al. (2012) estimated that the difference between the hatching of first and last spawned egg strands could be over two months. However, it appears that with prolonged spawning and hatching periods and with spawning occurring in various depths and at various temperatures, perch have evolved a powerful mechanism to protect their population against the instability of the water environment. Annually, this spawning strategy ensures sufficient recruitment despite the vagaries of the weather and temporary bad biological conditions (e.g. lack of an appropriate food) in the lake (Čech et al., 2012). Spawning in deep water could also protect parental fish from predators (e.g. pike Esox lucius in the case of Chabařovice Lake) since during the spawning fish lose their normal behaviour (Craig, 1987) and, especially in shallow, warm water they would be more vulnerable to predation.

\section{CONCLUSION}

The present study has shown the importance of wind protected bays and flooded vegetation on the distribution of egg strands of perch in large water bodies, particularly in their shallow littoral zones. In Římov Reservoir, the spawning activity of perch in grass bays was eight times higher compared to the main reservoir body (more exposed to winds, less flooded vegetation present) and 35 times higher compared to rocky bays where the flooded vegetation was completely absent. Excluding temperature, UVR or presence of appropriate spawning substrate, one of the most important factors affecting the distribution of perch egg strands in deeper depth layers seems to be water clarity. In Rímov Reservoir, perch did not spawn in layers of complete darkness starting around the depth of $6 \mathrm{~m}$. Contrary to that, in Chabařovice Lake where the light penetrates to three times greater depth perch frequently spawn to a depth of $12 \mathrm{~m}$ or even deeper.

Based on the recent knowledge it could be concluded that overall oligotrophication and warming of European inland waters (Molinero et al., 2006) will, in the near future, force perch to spawn in deeper and deeper water. At least in lakes and reservoirs, this would make the studies of perch reproduction success even more difficult, forcing SCUBA divers to also monitor depths of over $20 \mathrm{~m}$ to get a true picture of the real depth distribution, size and numbers of spawned egg strands (Čech et al., 2010).

\section{ACKNOWLEDGEMENTS}

The authors thank M. Morris for careful reading and correcting the English. The study was supported by the Grant Agency of the Czech Republic (project No. 206/06/1371 and 206/09/P266), by the Czech Ministry of Agriculture (project QH81046), the Vltava River Authority and the Palivový kombinát Ústí, státní podnik.

\section{REFERENCES}

Aalto S.K. and Newsome G.E.B., 1989. Evidence of demic structure for a population of yellow perch (Perca flavescens). Can. J. Fish. Aquat. Sci., 46, 184-190.

Ali M.A., Ryder R.A. and Anctil M., 1977. Photoreceptors and visual pigments as related to behavioral responses and preferred habitats of perches (Perca spp.) and pikeperches (Stizostedion spp.). J. Fish. Res. Board Can., 34, 1475-1480. 
Anneville O., Kaiblinger C., Tadonléké R.D., Druart J.-C. and Dokulil M.T., 2008. Contribution of longterm monitoring to the European Water Framework Directive implementation. In: Sengupta M. and Dalwani R., Proceedings of Taal2007: The 12th World Lake Conference, pp. 1122-1131.

Čech M. and Kubečka J., 2006. Ontogenetic changes in the bathypelagic distribution of European perch fry, Perca fluviatilis monitored by hydroacoustic methods. Biologia, Bratislava, 61, 211-219.

Čech M., Peterka J., Říha M., Jůza T. and Kubečka J., 2009. Distribution of egg strands of perch (Perca fluviatilis L.) with respect to depth and spawning substrate. Hydrobiologia, 630, 105-114.

Čech M., Peterka J., Říha M., Draštík V., Kratochvíl M. and Kubečka J., 2010. Deep spawning of perch (Perca fluviatilis L.) in the newly created Chabařvice Lake, Czech Republic. Hydrobiologia, 649, 375-378.

Čech M., Peterka J., Říha M., Muška M., Hejzlar J. and Kubečka J., 2011. Location and timing of the deposition of egg strands by perch (Perca fluviatilis L.): the roles of lake hydrology, spawning substrate and female size. Knowl. Managt. Aquatic Ecosyst., 403, 1-12.

Čech M., Vejř́k L., Peterka J., Říha M., Muška M., Jůza T., Draštík V., Kratochvíl M. and Kubečka J., 2012. The use of artificial spawning substrates in order to understand the factors influencing the spawning site selection, depth of egg strands deposition and hatching time of perch (Perca fluviatilis L.). J. Limnol., 71, 170-179.

Clady M.D. and Hutchinson B., 1975. Effect of high winds on eggs of yellow perch, Perca flavescens, in Oneida Lake, New York. T. Am. Fish. Soc., 104, 524-525.

Craig J.F., 1987. The biology of perch and related fish. Croom Helm Ltd, Kent.

Dalimier N., Philippart J.C. and Voss J., 1982. An eco-ethological study of the reproduction of Perca fluviatilis L. as observed by diving in an inundated quarry pit. Cahiers d'Éthologie Appliquée, 2, 37-52 (in French with summary in English).

Gerdeaux D. and Perga M.-E., 2006. Changes in whitefish scales $\delta^{13} \mathrm{C}$ during eutrophication and reoligotrophication of subalpine lakes. Limnol. Oceanogr., 51, 772-780.

Gillet C. and Dubois J.P., 1995. A survey of the spawning of perch (Perca fluviatilis), pike (Esox lucius), and roach (Rutilus rutilus), using artificial spawning substrate in lakes. Hydrobiologia, 300-301, 409-414.

Gillet C. and Dubois J.P., 2007. Effect of water temperature and size of females on the timing of spawning of perch Perca fluviatilis L. in Lake Geneva from 1984 to 2003. J. Fish Biol., 70, 1001-1014.

Guma'a S.A., 1978. The effects of temperature on the development and mortality of eggs of perch, Perca fluviatilis. Fresh. Biol., 8, 221-227.

Hergenrader G.L., 1969. Spawning behavior of Perca flavescens in aquaria. Copeia, 1969, 839-841.

Holčík J., 1969. The natural history of perch, Perca fluviatilis, Linneaus 1758, in the Klíčava reservoir. Práce Laboratoria Rybárstva, 2, 269-305.

Houde E.D., 2008. Emerging from Hjort's shadow. J. Northw. Atl. Fish. Sci., 41, 53-70.

Huff D.D., Grad G. and Williamson C.E., 2004. Environmental constraints on spawning depth of yellow perch: the roles of low temperature and high solar ultraviolet radiation. T. Am. Fish. Soc., 133, 718-726.

Jacobsen L., Berg S., Broberg M., Jepsen N. and Skov C., 2002. Activity and food choice of piscivorous perch (Perca fluviatilis) in a eutrophic shallow lake: a radio-telemetry study. Fresh. Biol., 47, 2370-2379.

Jones D.H., 1982. The spawning of perch (Perca fluviatilis, L.) in Loch Leven, Kinross, Scotland. Fish. Manag., 13, 139-151.

Jůza T., Čech M., Kubečka J., Vašek M., Peterka J. and Matěna J., 2010. The influence of the trawl mouth opening size and net colour on catch efficiency during sampling of early fish stages. Fish. Res., 105, 125-133.

Jůza T., Čech M., Kubečka J., Vašek M., Peterka J., Kratochvíl M., Frouzová J. and Matěna J., 2012. The influence of the trawl mouth opening size and net colour on catch efficiency during sampling of early stages of perch (Perca fluviatilis) and pikeperch (Sander lucioperca) in the bathypelagic layer of a canyon-shaped reservoir. Fish. Res., 123-124, 21-25.

Kratochvíl M., Mrkvička T., Vašek M., Peterka J., Čech M., Draštík V., Jůza T., Matěna J., Muška M., Sed'a J., Znachor P. and Kubečka J., 2012. Littoral age 0+ fish distribution in relation to multiscale spatial heterogeneity of a deep-valley reservoir. Hydrobiologia, 696, 185-198. 
Kubečka J., 1992. Fluctuations in fyke-net catches during the spawning period of the Eurasian perch (Perca fluviatilis) in the Římov Reservoir, Czechoslovakia. Fish. Res., 15, 157-167.

Mansueti A.J., 1964. Early development of the yellow perch, Perca flavescens. Chesapeake Science, 5, 46-66.

Molinero J.C., Anneville O., Souissi S., Balvay G. and Gerdeaux D., 2006. Anthropogenic and climate forcing on the long-term changes of planktonic rotifers in Lake Geneva, Europe. J. Plankton Res., $28,287-296$.

Moyle P.B. and Cech J.J., 1982. Fishes: An Introduction to Ichthyology. New Jersey: Prentice-Hall, Inc.

Newsome G.E. and Aalto S.K., 1987. An egg-mass census method for tracking fluctuations in yellow perch (Perca flavescens) populations. Can. J. Fish. Aquat. Sci., 44, 1221-1232.

Probst W.N., Stoll S., Hofmann H., Fischer P. and Eckmann R., 2009. Spawning site selection by Eurasian perch (Perca fluviatilis L.) in relation to temperature and wave exposure. Ecol. Fresh. Fish, 18, 1-7.

Říha M., Kubečka J., Vašek M., Sed'a J., Mrkvička T., Prchalová M., Matěna J., Hladík M., Čech M., Draštík V., Frouzová J., Hohausová E., Jarolím O., Jůza T., Kratochvíl M., Peterka J. and Tušer M., 2009. Long-term development of fish population in the Rímov Reservoir. Fish. Manag. Ecol., 16, 121-129.

Rozmajzlová-Řeháčková V., 1966. A hydrobiological study of the water-supply reservoir on the Klíčava near Zbečno during 1952-1959. In: Hrbáček J. (ed.), Hydrobiological Studies 1, Academia Publishing House of the Czechoslovak Academy of Sciences, Prague, pp. 165-220.

Smith C., Douglas A. and Jurajda P., 2001. Oviposition site selection and embryo mortality in perch. J. Fish. Biol., 58, 880-882.

Snickars M., Sundblad G., Sandström A., Ljunggren L., Bergström U., Johansson G. and Mattila J., 2010. Habitat selectivity of substrate-spawning fish: modeling requirements for the Eurasian perch Perca fluviatilis. Mar. Ecol. Prog. Ser., 398, 235-243.

Swift D.R., 1965. Effect of temperature on mortality and rate of development of the eggs of the pike (Esox lucius L.) and the perch (Perca fluviatilis L.). Nature, 206, 528.

Treasurer J.W., 1983. Estimates of egg and viable embryo production in a lacustrine perch, Perca fluviatilis. Environ. Biol. Fish., 8, 3-16.

Urho L., 1996. Habitat shifts of perch larvae as survival strategy. Ann. Zool. Fenn., 33, 329-340.

Viljanen M. and Holopainen I.J., 1982. Population density of perch (Perca fluviatilis L.) at egg, larval and adult stages in the dys-oligotrophic Lake Suomunjärvi, Finland. Ann. Zool. Fenn., 19, 39-46.

Williamson C.E., Metzgar S.L., Lovera P.A. and Moeller R.E., 1997. Solar ultraviolet radiation and the spawning habitat of yellow perch, Perca flavescens. Ecol. Appl., 7, 1017-1023.

Wootton R.J., 1998. The Ecology of Teleost Fishes. Dordrecht, Kluwer Academic Publishers. 